\title{
Narrating the History: The Reinterpretation of Symbolic Reparation for the Reconciliation and Redemption of Child Victims of Conflict
}

\author{
Diana Carolina Cañaveral Londoño \\ Lawyer of La Gran Colombia Seccional Armenia University, in Armenia-Quindío, Colombia, Candidate for Master's \\ degree in Public Law at the same University, Researcher, member of the Law, State and Citizenship Research Group of \\ the Universidad la Gran Colombia Seccional Armenia
}

\begin{abstract}
:
In Colombia there is a large sector of the population that has been the object of violation and ignorance of their human rights. They, like all victims of this type of violation, need to be repaired in a comprehensive manner. The concept of symbolic reparation that includes this integral reparation aims to reclaim the human being, to reconstruct it from the wounds and traces left by the violation of human rights in his memory. In a more sympathetic sense than is usually attributed to it, it seeks to bring the practice and experience of individuals to a level of abstraction that allows them to conceptualize a specific fact and articulate it with other concepts, so that the individual acquires adequate resilience. In this sense, the exercise and the experience of this reconstruction through the narratives, can provide certain conditions that make possible the process of symbolic reparation, which is exactly what it is tried to demonstrate with this investigation. This document is part of the research entitled "The narratives as a mechanism for the symbolic reparation of children victims of human rights violations", which seeks to understand the factors that make it possible to implement narratives as a mechanisms for symbolic reparation of children who are victims of human rights violations, as opposed to the symbolic reparations that have been erroneously ordered by the Inter-American Court of Human Rights and the Colombian Supreme Court and Constitutional Court.
\end{abstract}

Keywords: Human rights, human rights violations, Peace research, Child welfare, Social justice

\section{Introduction}

Your eyes have your age,

but your ears have the age of your parents.

Proverb of Afar People (Vázquez \& Francica, 2016, p. 78).

In Colombia there is a large sector of the population that has been victim of violation and ignorance of their human rights. They, like all victims of this type of rape, need to be repaired in a integral way. The concept of Symbolic Reparation that includes this integral reparation aims to reclaim the human being, to reconstruct it from the wounds and footprints that the violation of human rights left in his memory. In a more comprehensive sense than is usually assigned, Symbolic Reparation seeks to bring the practice and experience of individuals to a level of abstraction that allows them conceptualizing a particular fact, and articulating it with other concepts, so that the individual acquires a capacity of adequate resilience. In this sense, the exercise and the experience of this reconstruction through the narratives, can provide certain conditions that make possible the process of symbolic reparation, and that is precisely what this investigation is tried to demonstrate.

This paper is a result of the research entitled "The narratives as a mechanism for Symbolic Reparation of children victims of human rights violations" wich general objective is to understand the factors that make it possible to implement narratives as a mechanism for Symbolic Reparation of children victims of human rights violations in the department of Quindío. In addition, one of the specific objectives proposed within this research was to conceptualize, around the symbolic reparation, the different scope and elements that are proper to this measure, as well as to describe the elements that the narratives contribute within said process and that could be sufficient to achieve the objective of this repair. To do this, it was necessary to make an exercise of bibliographic revision around primary and secondary sources related to the topic of symbolic 
reparation and narratives, and also around certain jurisprudence of the Inter-American Court of Human Rights and of the Constitutional and Supreme Courts of Justice of Colombia, all this in order to conceptualize about some of the categories of analysis that were identified within the aforementioned research, to conform the conceptual framework of the same and to develop the two objectives indicated above. The research to which the present article belongs is of a socio-juridical type, of qualitative class, and the method used is the Hermeneutic Method with a Biographical-Narrative approach. The instruments used to collect the information are the interviews, observations, autobiographical writings, life stories and photographs, in addition to the information that can be supplied by the Historical Memory Center of Colombia. The technique of analysis is discourse analysis.

\section{The Duty to Repair Victims of Human Rights Violations}

For more than five decades, the Colombian context has been defined by an armed conflict of a non-international character that has, as one of its most important and emphatic characteristics, the presence of victims, direct and indirect, of all genres, conditions and ages. Such victims are because the conflict has ignored and violated their essential rights, their human rights, and in the special case of children, their prevailing rights. And that prevalence of the rights of children in Colombia is what leads us to affirm that the violation of the rights of those who are entitled, and that have been recognized as of a higher value because of its importance and need for promotion and protection, to the point of calling them "human rights" (UNESCO, 2012), is -and must be a priority focus for both the State and society in general.

However, according to the results of the on-site visit by the Inter-American Commission on Human Rights in 2013, the Colombian context was characterized not only by the existence of an internal armed conflict that left numerous victims of all ages and regions of the Country, but also because of the presence of a number of basic rights and needs that are unsatisfied in a large part of the population, and because of the inadequacy of the legal and governmental mechanisms available to achieve this satisfaction (Inter-American Commission on Human Rights, 2013, p. 269). And it is precisely these victims who need to be repaired -because they have been subjected to violation and ignorance of their human rights, and that reparation most be both patrimonial and perhaps -and this is what is proposed through this research, emotionally and ontologically.

Resolution 60/147, adopted by the UN General Assembly on 16 December 2005, sets out the basic principles and guidelines on the right of victims of human rights violations to lodge and receive reparations. In that resolution, the Assembly emphasizes the victims' right to be treated with compassion and respect for their dignity, and the right to access justice and redress mechanisms, and to clarify that while the duty to make reparation lies at the head of the direct responsible (which is often different from the State), it is the State that, in its guarantor position of the respect and application of human rights and international law on the subject, wich is in the duty not only to incorporate those norms to the domestic law, but also to adopt all the procedures that effectively tend to ensure equitable, effective and prompt access to justice and to the establishment of sufficient resources for the victims reachs the correspondat reparation (United Nations, 2005). By virtue of such content, Resolution 60/147, insofar as it allows for the promotion of justice in the face of any serious violation or ignorance of human rights, includes a guideline necessary to guarantee and achieve the due fulfillment of all those International Treaties that promotes and recognizes the high character of human rights.

In this way, ensuring the establishment of reparation mechanisms and alternatives for victims of human rights violations is an international duty of the States to which they are committed, not by Resolution 60/147 (which is only a guideline developing truly binding instruments), but rather by subscribing to the various international instruments that recognize and declare the paramount importance of human rights, such as the Universal Declaration of Human Rights, the International Covenant on Civil and Policy, the Convention on the Rights of the Child, the Haya Convention and the Additional Protocols to the Geneva Conventions, among others ${ }^{1}$.

However, following the guidelines contained in the aforementioned Resolution, the Colombian State incorporated, through Law 1448 of 2011 related to Victims' Law and Land Restitution, a series of procedures and mechanisms that seek, among other things, to allow access of victims to reparation systems. This means that the Colombian State recognizes its duty to guarantee the victims -although only those who are victims of the internal armed conflict, access to reparation, which, in principle, seems to terms of UN Resolution 60/147.

\footnotetext{
1 Judith Lichtenberg, "Negative Duties, Positive Duties, and the 'New Harms," Ethics 120 (2010): 557-578 at 561-562.
} 
In any case, it is necessary to recall that, as the Inter-American Court of Human Rights has pointed out, the obligation of States to make reparations to victims of human rights violations is, in itself, the rationale of the system of international protection of human rights, from which it is inferred the exigibility of this duty to make reparation to the victims, by means of actions before said international jurisdiction:

The international protection of human rights should not be confused with criminal justice. States do not appear before the Court as defendants in a criminal action. The objective of international human rights law is not to punish those individuals, who are guilty of violations, but rather to protect the victims and to provide for the reparation of damages resulting from the acts of the States responsible.

The State has a legal duty to take reasonable steps to prevent human rights violations and to use the means at its disposal to carry out a serious investigation of violations committed within its jurisdiction, to identify those responsible, to impose the appropriate punishment and to ensure the victim adequate compensation (Inter-American Court of Human Rights, 1988, pp. 134, 174).

Likewise, in the Final Agreement for the Termination of the Conflict and the Construction of a Stable and Durable Peace, signed by the Colombian National Government and the Central Command of the Central Staff of FARC-EP on November 24, 2016 in the city of Bogotá, both parties entered into a series of commitments aimed precisely to securing a definitive end to the armed conflict between the State and the guerrilla group and establishing the minimum (although very specific) basis for building a solid peace. One of these commitments, as folio 127 et seq. of said Agreement, was the creation of an Integral System of Truth, Justice, Reparation and Non-Repetition, one of whose components is the following:

Measures of integral reparation for peace-building: These are measures that seek to ensure the integral reparation of victims, including rights to restitution, compensation, rehabilitation, satisfaction and non-repetition; and collective reparation of the territories, populations and groups most affected by the conflict and most vulnerable, within the framework of the implementation of the other agreements. To this purpose, existing mechanisms will be strengthened, further action will be taken, and everyone's commitment to redressing the damage caused will be promoted (High Commissioner for Peace, 2016, pp. 129-130) (Translated by the author).

Although this Integral System of Truth, Justice, Reparation and Non-Repetition is hardly in the stage of structuring, the text of the agreement thus signed may infer an obligation on the part of Colombian State, and even on the part of the ex-guerrilla group FARC-EP, to proceed -in the near future, to a reparation of the victims of the Colombian armed conflict, in the precise terms of Resolution 60/147 mentioned above, through the tools offered by said System, whose components are the (High Commissioner for Peace, 2016, p. 125):

- The Commission for the Clarification of Truth, Coexistence and Non-Repetition.

- The special unit to search for missing persons in the context and due to the armed conflict.

- The Special Jurisdiction of Peace.

- The set of integral reparation measures for the construction of peace.

- The Non-Repetition Warranties.

Thus, it is from these instruments, norms, judicial antecedents and expectations, from which arises the duty of the States, and specifically of the Colombian State, to repare the victims of human rights violations, understanding, of course, that the victims of the armed conflict are also, and for that reason, victims of serious violations of their human rights.

However, it being clear that there is a duty of the State in this regard, it is necessary to reflect close to who, in the current Colombian context, are holders of the right to reparation.

\section{Characterization of Victims of Human Rights Violations}

Regarding the characterization of victims of human rights violations, Resolution 60/147 establishes that "victims" are all persons who have suffered damages, individually or collectively, including physical or mental injuries, emotional suffering, economic loss or impairment fundamental rights, as a result of acts or omissions that constitute a manifest violation of international human rights norms, or a grave breach of international humanitarian law, including the immediate family or 
persons in charge of the direct victim and the persons who have suffered harm in intervening to provide assistance to victims at risk or to prevent victimization (United Nations, 2005). As inferred from the above characterization, the quality of victim occurs regardless of the context surrounding the victimizing acts, that is to say, regardless of whether the human rights violations occur within the framework of an international or non-international armed conflict or not.

However, Law 1448 of 2011 -which determines, at the domestic level, the duty of the State to establish and define the mechanisms to achieve reparation of victims, does establish a restriction in the sense of considering as such, only those persons that had been individually or collectively harmed by events that had occurred since 1 January 1985 and as a result of violations of international humanitarian law or of grave and manifest violations of international human rights standards that had occurred during the armed conflict (Article 3). Right now, in addition to Law 1448 of 2011 and its statutory decrees (including 4800 of 2011), no other legislation in Colombia establishes a duty, at the head of the State, to repare and compensate victims that had acquired this quality for another reasons differents than the internal armed conflict. This situation leaves all those people who have suffered different violations of their human rights for causes outside the internal armed conflict, out of the normative scope provided for there, which excludes a large section of the victimized population.

On the other hand, the Final Agreement for the Termination of the Conflict and the Construction of a Stable and Durable Peace signed by the Colombian National Government and the Central Command of FARC-EP, does not define precisely who will be understood in the condition of a victim capable of benefiting from the measures and mechanisms that will be implemented when the document be signed. What it does say, in a very vague reference to the Program for Integral Reparation of Victims (created by Law 1448 of 2011), is that a "victimization map" must be constructed, in wich -among other things were included and registered in the universe of victims inscribed in that mencioned Program for Integral Reparation of Victims (High Commissioner for Peace, 2016, p. 185). Although there is currently no certainty about this aspect within the current framework of post-conflict in Colombia, this could mean that the future process of recognition of victims will be somewhat less strict and rigorous than that which has been applied to the interior of the Unit for Integral Care and Reparation for Victims, but will continue to imply, in any case, a substantial limitation on access to the right to reparation, while again excluding all victims of human rights violations that would have reached this quality for another reasons differents than internal armed conflict in Colombia1.

In spite of the above, the victims that constitute the object of study and the proposal that is brought here are those children who have been violated in their human rights, including the right to special protection for physical development -mental and social, education, understanding and love of parents and society, to receive help in all circumstances and protection against all forms of neglect, cruelty and exploitation (United Nations, 1959), which are just some of the rights that the country's children have been deprived of, without distinction to the cause of the victimizing event. And it is not only within the context of an armed conflict that human rights violations occur; as expressed by the General Assembly of the United Nations through Resolution 60/147, by refraining from establishing, as a prerequisite of the right to integral reparation, that the violation of human rights had occurred for one reason or another determined.

Thus, it is already clear that there is a duty to repair and to whom have the right to claim such reparation. It is now necessary to go on to establish what are the characteristics that must meet the reparation to which the States are obliged, specifically the Colombian State.

\section{What is the Repair to which Forces the UN 60/147 Resolution?}

In accordance with the terms of Article 18 of UN Resolution 60/147, reparation of victims of human rights violations must be complete and effective and include the following forms: restitution, compensation, rehabilitation, satisfaction and guarantee of non-repetition. The hermeneutic reading of this stipulation, based on an non-positivist (or inclusive, or axiological positivism) posture, makes it possible to infer that the intention of the UN General Assembly to establish the duty to make reparation in these aspects was to compel an integral reparation, in order to cover all the aspects that would have been affected by the violation of human rights. This has been confirmed by, inter alia, the Inter-American Court of Human Rights, for example, when it states:

\footnotetext{
1 See, e.g., John Thøgersen and Ulf Schrader, "From Knowledge to Action - New Paths Towards Consumption," Journal of Consumer Policy 35 (2012): 1-5; William Young et al., "Sustainable Consumption: Green Consumer Behaviour when Purchasing Products," Sustainable Development 18 (2010): 20-31.
} 
Reparations are measures tending to eliminate the effects of the violations committed. Their nature and amount depend on the characteristics of the violation and on both the pecuniary and non-pecuniary damage caused. Such reparations shall not result in the victims or their successors becoming richer or poorer and they shall be commensurate with the violations declared in the Judgment (Inter-American Court of Human Rights, 2006, p. 110).

This reparation, on the material and immaterial levels of the victim, has been called integral reparation or restitutio in integrum, which, in addition, is consistent with the classification of reparable items defined by the Office of the Special Rapporteur of the United Nations, within the Draft Principles and Basic Guidelines relating to the redress of gross violations of human rights, according to which reparation of victims should include restitution, compensation, reconstruction of the life project, satisfaction and guarantees of non-repetition (United Nations Commission on Human Rights, 1993). (Highlighted out of text).

It is worth mentioning, at this point, that for the purposes of this document, the reconstruction of the life project and measures of satisfaction are of particular importance. The Inter-American Court of Human Rights has defined the first, that is, the reconstruction of the life project -or life plan:

The so-colled 'life plan' deals with the full self-actualisation of the person concerned and takes account of her calling in life, her particular circumstances, her potentialities, and her ambitions, thus permitting her to set for herself, in a reasonable manner, specific goals, and to attain those goals" (Inter-American Court of Human Rights, 1998, p. 37).

The second, that is, the measures of satisfaction, involve the inclusion of provisions such as verification of facts and full public disclosure of truth, search for missing persons, official statements or judicial decisions that restore dignity, reputation and rights of the victim, public apologies including acknowledgment of the facts and acceptance of responsibilities, commemorations and tributes to the victims, and the inclusion of precise references to the violations in the teaching of international standards of human rights and international humanitarian law (United Nations, 2005).

The reparation of victims, which must be, as has been said, in a comprehensive manner, entails not only the coverage of the pecuniary aspects that will eventually serve to restore assets and resources lost during the rape -insofar as this is possible, but also involves the satisfaction of certain aspects that were affected by the same violation of human rights, aspects closely linked to both the life project and the victim's emotions.

\section{Scope of Integral Repair and Rol of Symbolic Repair}

Having said all this, it is pertinent to bring up the proposal named by Velásquez Zapeta, in 2008, as Maya Kem strategy. According to this, the integrality in the reparation of victims is reached when there is "the synergic articulation of the compensation measures that are applied in a certain place, at the same time and with the democratic participation of the same beneficiary population, at community level, municipal, regional or departmental" (Velásquez Zapeta, 2008, p. 199) (Translated by the author). This strategy involves three forms of work: the active participation of the victims in the design, planning and execution of the repair strategy; respect for victims as subjects of rights and as the ultimate reason for all activity; and the conception of the strategy as a dynamic of flexible application of compensation measures:

Material restitution operations are conceived as a medium around which qualitative and intangible operations (such as cultural restitution and psychosocial reparation) are developed, and it is hoped that these intangible measures will be able to remain longer in each community and that achieve the desired effects of increasing self-esteem and self-valuation of people as citizens subjects of rights (Velásquez Zapeta, 2008, p. 200) (Translated by the author).

However, as stated above, the Colombian context makes it possible to highlight the presence of child victims who have been or have been subjected to ignorance and violation of their human rights, and who, for this reason, need to be repaired, not only from a patrimonial-material perspective, but also, and in addition, from an emotional-immaterial, integral, and ontological perspective. Within that concept of integral reparation that seeks to claim being and allow the reconstruction of his life project from the wounds and traces that the violation of human rights left in his memory, symbolic reparation plays an important role for these effects as long as it seeks to bring the practice and experience of individuals to a level of abstraction that allows one to conceptualize a given fact and articulate it with other concepts so that the individual acquires adequate resilience. This has been hinted in a large part of international doctrine: "[symbolic reparation] can fulfill a relevant psychological function, helping the personal rupture with the traumatic past to which has been bound since the moment of the violation, and helping to integrating it to the present" (Beristaín, 2010, p. 120) (Translated by the author). 
Thus, the purpose of symbolic reparation consists precisely in allowing the victim, on the one hand, to redefine and resignify his own perception, that is, the perception he has of himself in front of the world around him, and on the other side, to rebuild his project of life from the new story that he has set it. This is precisely the same claim of integral reparation raised within the Maya Kem Strategy. In this sense, it is considered that the exercise and the experience that this process of resignification and reconstruction make the victim through the narratives, enables the achievement of the claims and objectives of the integral reparation to which States are bound, in the way that is going to be explain in the next chapter.

However, attention should be drawn to the fact that in the Final Agreement for the Termination of the Conflict and the Construction of a Stable and Durable Peace subscribed by the Colombian Government and the FARC-EP, no further mention is made of this type of repair. At first, it is established that the Tribunal for Peace:

Without prejudice to the competence of the State Council in respect of monetary reparations, it [the Tribunal for Peace] may establish symbolic restorative obligations to the State and organizations respecting due process and provided that the organization or State has omitted effective procedures to prevent punishable conduct (High Commissioner for Peace, 2016, p. 162) (Translated by the author).

And then, in a second and final moment, it was agreed that collective reparation plans with a territorial approach should include, as one of its elements, "Material and symbolic measures aimed at attending the damage [...] guided to direct victims, individual and collective, such as actions of dignity, memory, homage and commemoration, infrastructure works and commemorative architecture "(High Commissioner for Peace, 2016, p.180).

Thus, although the symbolic reparation fulfills this remarkable resignifying function of the victim, being one of the most important and dignifying aspects of the integral reparation ordered by UN Resolution 60/147, it has not had -until the moment, the scope that corresponds within the Colombian post-conflict scenario.

\section{Why the Narratives?}

We are voices in a chorus that transforms lived life into narrated life

and then returns narrative to life,

not in order to reflect life,

but rather to add something else,

not a copy but a new measure of life;

to add, with each novel, something new, something more, to life.

Our life and everyone's life -there is no narrative adventure that,

somehow, is not a personal as well as a collective adventure,

the experience and destiny of one and all.

(Fuentes, 1985)

Within a society in conflict such as Colombia, the victims -not only of the armed conflict but all those that are of the different violations of human rights, in addition to claiming recognition as such, demand an effective reparation that allows them to attend to their resilience process. Such a process does not occur, as has been said, by obtaining a pecuniary compensation or similar, but requires a true commitment towards the recognition of the other as the constructive subject of existence, reality and subjectivity of each victim. It requires the insertion and use of symbols that are part of the imaginary of individuals and that allow the apprehension of new values within the daily life of each being. In this sense, it is considered that the identification of the narratives that facilitate that process of resilience, and the understanding of the tools that each of them can contribute in that process, is the mechanism that can possibly transform the silence of children who are victims of human rights violations, in real, individual, and powerful voices, that will reinterpret the process of adaptation, overcoming and reconstruction of a new reality.

Why the narratives? It was previously said that integral reparation has a purpose of rebuilding the social fabric, and that such integrality is achieved insofar as the compensation strategies involve simultaneously the strateegy of redress and the 
individual himself as a subject of reparation. However, it is not possible to define narratives based on a precise notion of a particular activity, because it would be reducing its ability to articulate and produce meaning within a discourse.

Narratives, according to Anderson's understanding of them, are a two-way discursive process that involves the narrator and all the world wich surrounds him, to construct a new and improved meaning of life:

Narratives refers to a form of discourse, the discursive way in which we organize, account for, give meaning to, and understand, that is, give structure and coherence to, the circumstances and events in our lives, to the fragmens of our experiences, and to our self-identities, for and with ourselves and others. Narrative is a dynamic process that constitutes both the way that we organize the events and experiences or our lives to make sense of them and the way we participate in creating the things we make sense of, including ourselves... Our stories form, inform, and re-form our sources of knowledge, our views of reality... however, narrative is more hthan a storytelling metaphore; it is a reflexive two-way discrusive process. It constructs our experiences and, in turn, is used to understand our experiences (Anderson, 1997, pp. 212-213).

Therefore narratives, whatever their form, and the methodologies that they incorporate (which contemplate routes that allow the inclusion of the voice and memories of the victims, the retrieval of documentary material, oral testimonies which leads to historical enlightenment and reconstruction of local memories, and make possible this symbolic reparation in addition to the generation of new knowledge and a certain guarantee of non-repetition), presupposes the reconstruction of the narrator's vision of events, a reconstruction that can be achieved either by written forms, or sounds, pictographic or other means. And precisely because of this, because the process of reconstruction of events involves the very voices of those who suffered -or still are suffering the violation of their human rights, the approach that should guide this process is the biographical-narrative, which allows and makes possible -according to Antonio Bolivar, the hermeneutic interaction of the following four elements:

(a) A narrator, who tells us about his life experiences; (b) An interpreter or researcher, who interpolates, collaborates and "reads" these stories to produce a report; (c) Texts, which include both what has been narrated in the field, and the subsequent report elaborated; and (d) Readers, who are going to read the published versions of narrative research. Therefore, the examination of narrative tales involves complex relationships between narrator, informants who have told us stories, and readers who interpret narrative forms from their frames of reference. Biographical accounts are texts to be interpreted (interpretandum) through another text (interpretans), which is basically the research report (Bolívar, 2010, p. 80)(Translated by the author).

Now, as the author mentioned above points out, once the stories that constitute the particular vision of each victim have been obtained, this narrative/story becomes a text/speech capable of being interpreted and, above all, capable of raising the voice of each one of the victims and resist the oblivion with which time and indifference conceal the individual and collective reality of each violation of human rights. In this sense, the recognition of the harm and pain that individually and collectively has suffered each victim, is especially important insofar as it allows, not only the individualization of each child as a particular subject within the conflict -and the postconflict, with its different and particular conditions and contexts that confer him or her a special and unique sense to his loss and his pain, but also allows the individualization of the precise measure of symbolic reparation that will enable, in that particular child, his repair, individual and -why not personalized.

And that is precisely the fault of the current measures of symbolic reparation that both the Colombian Constitutional Court and the Inter-American Court of Human Rights are ordering in those cases related to non-international conflicts and transitional justice: See, for example, the measure of symbolic reparation ordered by the Inter-American Court of Human Rights in the case of the Rochela Massacre v. Colombia, in which it was ordered:

A plaque with the date of the events and the names of the victims will be placed at the Courthouse of San Gil municipality, Santander department. Likewise, a photographic gallery of the victims will be installed in a visible and dignified place, with prior authorization from their representatives" (Inter-American Court of Human Rights, 2007, p. 81).

What does this measure say about each one of the victims whose names were recorded on that plaque? How can sons and daughters, wives and husbands, family and close friends feel repaired for the loss of their loved ones, by the inclusion of their names on a commemorative plaque? How can it talks about the particular context of each one of these victims, about the work they were doing, about their importance within a community, within a family? These immobile, inert 
measures, even when they try to recover the historical memory of the victims, do not really fulfill the purpose of the symbolic reparation of all the victims involved in that loss.

The exercise through narratives, on the other hand, focuses on the individuality of each person -in this case in each one of the children who have suffered some violation of their rights during the conflict, to intervene in an active and positive way in the process of narration, comprehension and resignification of each life experience, in order to contribute to the reconstruction of both the project of individual life that was affected by the conflict and the social fabric that was broken on the occasion of the same.

However, this exercise cannot remain solely in the recovery of such narratives/stories. The life histories narrated by children victims of human rights violations, in order to have the reparative effect that they are expected to have, should be read and, above all, interpreted in the mentioned two-way discrusive process. As González-Monteagudo said, quoting Fraser:

'Learning and change result from the integration of concrete emotional experiences with cognitive processes: conceptual analysis and understanding'. Through learning, the adult symbolically travels from dependence to autonomy, from passivity to activity, from selfishness to altruism, from self-rejection to self-acceptance, from imitation to originality, from narrow interests to broad interests (Fraser, 1995:9) (González-Monteagudo, 2017, p. 46).

For this reason, it is proposed a methodology of analysis -comprehensible and interpretive based on hermeneutics, but not that one which is possible within a single discipline, but that one which constitutes an interdisciplinary exercise, since human realities can not be approached, in the full extent of their complexity, from a single disciplinary field. For this reason, the narrative biographical method, which requires a hermeneutic perspective -in this case interdisciplinary, stands as the best mechanism to achieve the reading of the speeches that will constitute and shape the narratives, as the way that summarized by Bolivar:

Narrative-biographical research, as a branch of interpretive research, shares some of the general methodological principles of qualitative research, especially that interpretive or hermeneutic perspective, whose object is essentially discursive texts (Denzin and LINCOLN, 2006; VASILACHIS, 2006) (Bolivar, 2010, p. 79)(Translated by the author).

Thus, the mechanism proposed here through narratives becomes a dialogical exercise between victims and readers that, precisely because of this characteristic, makes possible reflection and with it also a change. One thing will be to read the conflict from the statistical data, or even from the same Peace Agreement, and another will be read it from the narrative made by anyone who has been affected by it, or by any other violation of their human rights. As the sociologist Sam Richards points out, regarding the possibilities offered by direct dialogue between the parties to the conflict: "These conversations, which previously seemed impossible to have, generate reflection, and reflection generates change" (Richards, 2016) (Translated by the author).

\section{Conclusion: Biographical-Narrative Exercise as an Act of Symbolic Reparation}

According to the insinuations above, narratives have some properties to make the narrator give a certain meaning to his reality, according to the experience and the ontological resources available to him, but also according to that rational process with which he deals with that reality; but this process can be -in many cases determined precisely by the wounds and emotions to which the traumatic experience leads the victim. And it is that, according to Bruner, life, experiences and reality in them are meaningless, because it is the individual, each person who lives, experiences and is immersed in a reality, who confers to this reality the sense that his judgment and his reflection allow him.

[...] The mimesis between life so-called and narrative is a two-way affair: that is to say, just as art imitates life in Aristotle's sense, so, in Oscar Wilde's, life imitates art. Narrative imitates life, life imitates narrative. "Life" in this sense is the same kind of construction of the human imagination as "a narrative" is. It is constructed by human beings through active ratiocination, by the same kind of ratiocination through which we construct narratives. When somebody tells you his lifeand that is principally what we shall be talking about-it is always a cognitive achievement rather than a through-the-clearcrystal recital of something univocally given. In the end, it is a narrative achievement. There is no such thing psychologically as "life itself" At very least, it is a selective achievement of memory recall; beyond that, recounting one's life is an interpretive feat. Philosophically speaking, it is hard to imagine being a naive realist about "life itself" (Bruner, 2004, p. 692).

Thus, the narrative process of a life story involves an expression of the way in which the person perceives and processes internally their experience and their own perception of their place in the world. In this way, a victimizing fact such as those 
involving a violation of human rights will be perceived -and narrated by the victim of the same, by the child who suffered this violation, in a way that will directly correspond to the capacity that has that child to understand that situation, to process it in his mind and to find a way to overcome it. And although the above-mentioned author argues that people are habituated to a certain way of perceiving their reality and their experience in the world, so they make it a kind of guide to structure all their experience and their future life (Bruner, 2004, p. 708), the fact is that narratives, because they involve a form of expression, an act of language (written, musical, pictorial, etc.) and therefore an "act of meaning" (Bruner, 1990) the capacity to provide to each child victims of human rights violations with the necessary tools to build and transform their reality, so they can understand it and, with it, give it a new, renewed sense that calms the pain and close the wounds with which this reality marked them.

In 2011, Angus \& Greenberg indicated, in what they called a Dialectic-Constructivist Narrative Model applicable to patients with a diagnosis of depression, that the process by which the patient exposes the narratives, the accompanying life stories, was fundational to he could give a new emotional meaning to his experience, and could attain a new understanding of himself (Angus, et al., 2012, p. 55). Although this model was designed for the treatment of patients with depression, it was intended to achieve that the experiences and perceptions that had led the patient to that state of depression, could be understood and articulated -through narratives- to other perceptions and images of himself, that allowed him to reach an emotional transformation, an emotional change, a healing of his wounds.

Further-more, they note that it is the narrative scaffolding of emotional experiences that provides a framework for the organization and integration of felt emotions with unfolding action sequences. For Angus and Greenberg (2011), core emotional experiences such as pain, hurt, sadness or loving compassion need to be situated and symbolized in the context of personal stories so that important information about a client's needs and goals, and the personal meaning of what happened, can be further articulated and understood...

The meaning of an emotion is understood when it can be organized within a narrative framework that identifies what is felt, about whom, in relation to a specific need or issue. As such, the reflexive processing and symbolization of clients' emotional experiences, in the context of salient personal stories, is viewed as a key intervention strategy that enables clients to meaningfully integrate their narrative and emotional lives, as a vehicle for therapeutic change (Angus, et al., 2012, p. 55).

According to the process written by these authors, narrative expression would allow victims of human rights violations a sincere and deep understanding of their own emotions, while allowing the visualization of different perceptions of themselves and their value in the world. In this way, it is considered that the implementation of this Model would be appropriate to achieve the other purposes of symbolic reparation, that is, to heal the wounds that the violation of human rights left in the child victims of the same.

\section{References}

[1] Anderson, H. (1997). Conversation, Language, and Possibilities. A Post Modern Approach to Therapy. New York: BasicBooks.

[2] Angus, L., Lewin, J., Boritz, T., Bryntwick, E., Carpenter, N., Watson-Gaze, J., y otros. (2012). Narrative Processes Coding System: A Dialectical Constructivist approach to assessing client change prcesses in Emotion-focused therapy of Depression. Research in Psychotherapy: Psychopathology, Process and Outcome , 15 (2), 54-61.

[3] Beristaín, C. (2010). Diálogos sobre la Reparación: Qué reparar en los casos de violaciones de derechos humanos. Costa Rica: Instituto Interamericano de Derechos Humanos.

[4] Bolívar, A. (2010). Methodology of Biographical-Narrative Research: Data collection and analysis. En M. y. Passeggi, Dimensões epistemológicas e metodológicas da investigação (auto)biográfica. (Vol. Tomo II, págs. 79-109). Porto Alegre: Editoria da PUCRS.

[5] Bruner, J. (1990). Acts of Meaning. Harvard University Press.

[6] Bruner, J. (2004). Life as a Narrative. Social Research , 71 (3), 691-710. Case of Loayza Tamayo v. Perú, Serie C Nro. 42 (Inter-American Court of Human Rights 7 de Novermber de 1998).

[7] Case of Acevedo Jaramillo et al. v. Perú (Inter-American Court of Human Rights 7 de February de 2006).

[8] Case of The Rochela Massacre v. Colombia (Inter-American Court of Human Rights 11 de May de 2007).

[9] Case of Velásquez Rodríguez v. Honduras (Inter-American Court of Human Rights 29 de July de 1988). 
[10] Fuentes, C. (31 de March de 1985). THE NOVEL ALWAYS SAYS: THE WORLD IS UNFINISHED. New York Times.

[11] González-Monteagudo, J. (2017). Biographical-narrative Methodologies for Adult Education. Between personal development and Critical Reflection. Culture, Biography \& Lifelong Learning , 3 (2), 45-65.

[12] High Commissioner for Peace. (24 de November de 2016). Final Agreement for the Ending of Conflict and the Construction of a Stable and Lasting Peace. Final Agreement for the Ending of Conflict and the Construction of a Stable and Lasting Peace , 310. Bogotá, Cundinamarca, Colombia: High Commissioner for Peace.

[13] Inter-American Commission on Human Rights. (2013). Verdad, Justicia y Reparación: cuarto informe sobre la situación de los derechos humanos en Colombia. OAS.

[14] Richards, S. (13 de May de 2016). They consider us dangerous because we question everything. Arcadia Magazine. (A. Gutiérrez, Entrevistador) Publicaciones Semana S. A.

[15] UNESCO. (19 de 11 de 2012). Children's Rights are Human Rights. (UNESCO, Productor) Recuperado el 11 de 11 de 2016, de UNESCO - Education: http://www.unesco.org/new/en/education/themes/strengtheningeducation-systems/early-childhood/single-view/news/childrens_rights_are_human_rights/.

[16] United Nations. (1959). Declaration of the Rights of the Child. Resolución 1386 de 1959. UN.

[17] United Nations. (2005). Resolution 60/147. Basic Principles and Guidelines on the Right to a Remedy and Reparation for Victims of Gross Violations of International Human Rights Law and Serious Violations of International Humanitarian Law. United Nations.

[18] United Nations Commission on Human Rights. (1993). E/CN.4/Sub.2/1993/8 - Study concerning the right to restitution, compensation and rehabilitation for victims of gross violations of human rights and fundamental freedoms. United Nations, Sub-Commission of Prevention of Discrimination and Protection of Minorities. United Nations.

[19] Vázquez, M., \& Francica, P. (2016). El hombre guionado. De la Moira a la libertad. Salta, Argentina: Ediciones Universidad Católica de Salta - EUCASA.

[20] Velásquez Zapeta, L. (2008). Maya Kem: nuevo paradigma de integralidad en el resarcimiento. En C. (. Díaz, Reparaciones para las Víctimas de la Violencia Política: estudios de caso y análisis comparado (págs. 200232). Centro Internacional para la Justicia Transicional (ICTJ). 